Origina

肝腫瘍に対する経皮的マイクロウェーブ凝固療法

佐藤 尚文, 青柳 秀忠, 荻原 裕之, 山田 勲, 小林 功

高井 良樹, 荒井 清充, 荻野 隆史, 三ッ木禎尚, 大嶋 清宏

武市 卒之，長谷川紳治，飯島 耕作，宮本 幸男*

\title{
Percutaneous Microwave Coagulation Therapy for the liver tumor
}

Naofumi Sato, Hidetada Aoyagi, Hiroyuki Ogiwara, Isao Yamada, Isao Kobayashi

Yoshiki Takai, Kiyomitsu Arai, Takashi Ogino, Sadanao Mitsugi, Kiyohiro Oosima

Takayuki Takeichi, Shinji Hasegawa, Kousaku Iijima and Yukio Miyamoto*

\begin{abstract}
Microwave coagulation therapy was applied to hepatocellurar carcinoma or metastatic liver tumor by percutaneous route. Our microwave apparatus have an ability of coagulation for the liver tumor up to $35 \mathrm{~mm}$ in diameter. Thus, in the treatment for the HCC or metastatic liver tumor, the size is within $35 \mathrm{~mm}$, this method is easy for practice, the most effective and less risky procedur.
\end{abstract}

Key words : percutaneous microwave coagulation, HCC, metastatic liver tumor

公立富岡総合病院 外科 个370-23 群馬県富岡市富岡 2073-1

Department of Surgery, Public Tomioka General Hospital

Address : 2073-1, Tomioka, Tomioka city, Gunma, 370-23, Japan

群馬県立医療短期大学 $* 371$ 群馬県前橋市上沖町 323-1

Gunma Prefectual College of Health Sciences

Address : 323-1, Kamioki-machi, Maebashi, Gunma, 371, Japan 


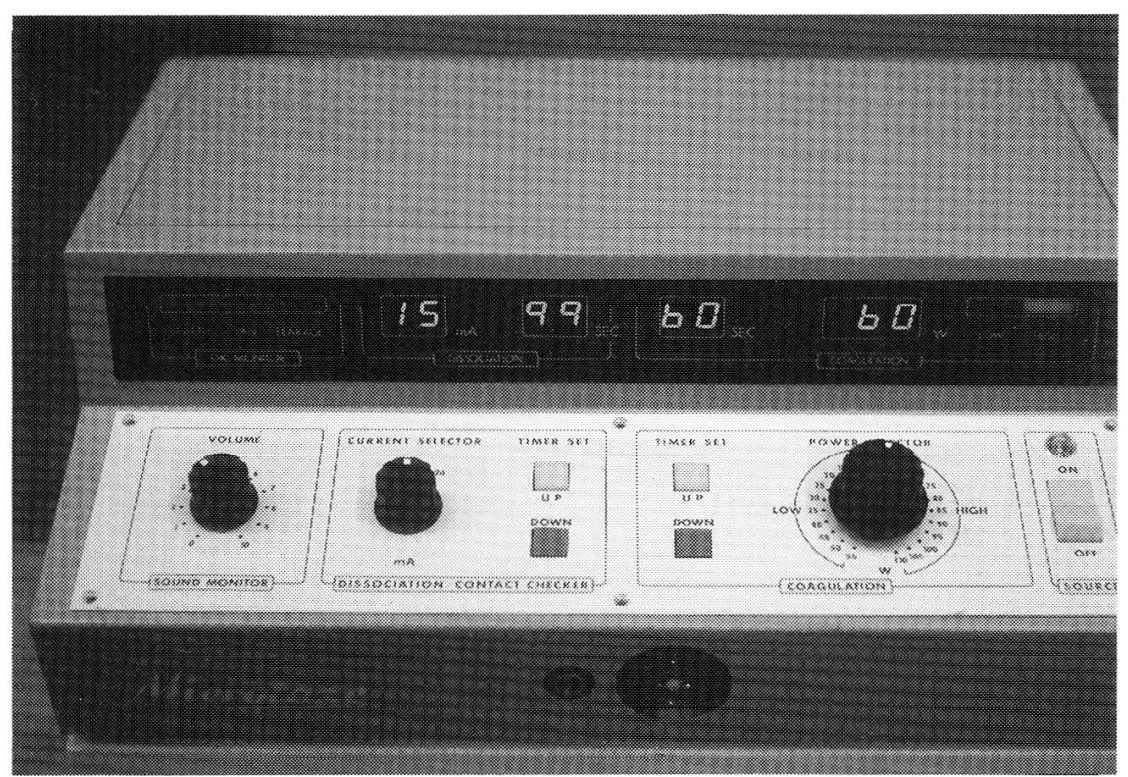

図1 マイクロターゼHSD20M

はじめに

肝腫瘍に対して, 電極を超音波ガイド下に経皮的穿 刺を行い, マイクロウェーブ凝固を行う治療 (Percutaneous Microwave Coagulation Therapy: 以下，PMCT）を考案して 3 年が経過した。本治療は極 めて低侵襲で，また熱凝固という物理的な腫瘍組織の 局所治療であり，効果が確実である。したがって孤立 性の肝細胞癌 (HCC) や転移性腫瘍の治療として, 今 後は第一選択の治療法になると思われる。本稿では, その実際の方法と, 治療後のCT, MRI像を中心に述べ たい。

\section{基礎実験}

実験および治療に使用したマイクロ波発生装置は, 平和電子工業社製マイクロターゼ HSD20M（図 1) で ある。直径 $2.2 \mathrm{~mm}$ の穿刺用電極をイ又の生体肝に穿 刺し, 凝固実験を行った。電極の先端を中心として, 球 状に凝固層が広がることが確認された。凝固出力およ び凝固時間に応じて凝固層が広がるが, 現在用いてい
る装置では, 出力 $60 \mathrm{~W}$, 凝固時間 30 分で凝固層の広が りはほほほプラトーに達した。イヌの生体肝臓ではこ の条件で直径 $35 \mathrm{~mm}$ の球状の凝固層が確認された。し かし組織学的な変性はさらに外側まで広がっていた。 したがって悪性病変の治療として, 確実な穿刺が行わ れれば，直経 $35 \mathrm{~mm}$ までの病変の凝固は確実である。 また熱変性による細胞変化はさらに外側まで及んでいる。

\section{臨床応用}

\section{1. 穿刺方法}

治療はすべて全身麻酔下に行う。治療に先立って, 超音波で適切な穿刺部位，体位を決めておく。またそ の位置から穿刺した場合の腫瘍径，腫瘍の表面までの 深さを正確に測定しておく。

今までに種々の穿刺針, 電極を用いて来たが, 現在 は $11 \mathrm{G}$ の外筒を有する穿刺針と, その外筒を通過する, 直径 $2.2 \mathrm{~mm}$, 長さ $200 \mathrm{~mm}$ の涙滴型電極を用いている (図 2)。

穿刺部位に約 $1 \mathrm{~cm}$ の皮切を加え，ここに高さ 4 〜 $5 \mathrm{~mm}$ に切った直径 $1 \mathrm{~cm}$ のシリコンチューブをはめ込 


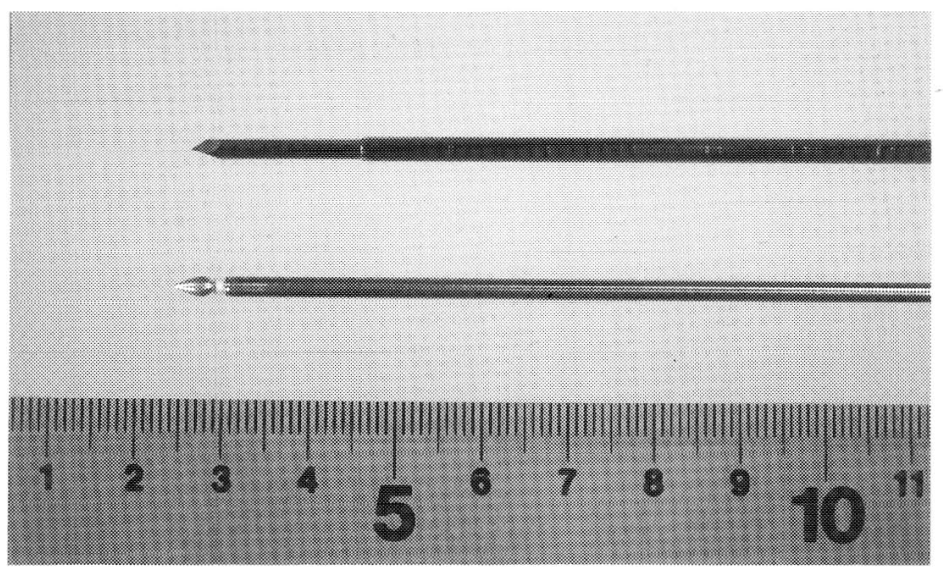

図2上：11G穿刺針

下 : $2.2 \mathrm{~mm}$ 涙滴型凝固電極

み，皮虑に縫合固定する。これは凝固中に加熱した電 極が皮膚に直接接触すると，熱傷を生じる恐れがある からである。穿刺針の先端が，外筒より腫瘍の半径に 相当する長さだけ出た状態で，穿刺針と外筒を固定し， 呼吸を止めた状態で一気に穿刺する。穿刺針の先端が 腫瘍の中心に達すると，外筒の先端が腫瘍の表面に位 置している事になる。次に穿刺針を抜去し，電極を挿 入する。そして直ちに凝固を開始する。

\section{2. 凝固}

凝固を開始すると, 電極の先端を中心に, high-echo 領域が出現する。この領域は発熱によって生じた micro-bableであり，この high-echo領域が充分に腫 瘍全体に広がるまで凝固を継続する（図 3)。出力は $60 \mathrm{~W}$ とし, 凝固時間は腫瘍径 $20 \mathrm{~mm}$ で 15 分, $30 \mathrm{~mm}$ で30分, それ以上では45 分から 60 分間凝固を行って いる。

凝固中は，かき水で穿刺部位周囲の皮膚を冷却する。 これにより，電極の加熱による術後の腹壁の浮腫を完 全に予防できる。

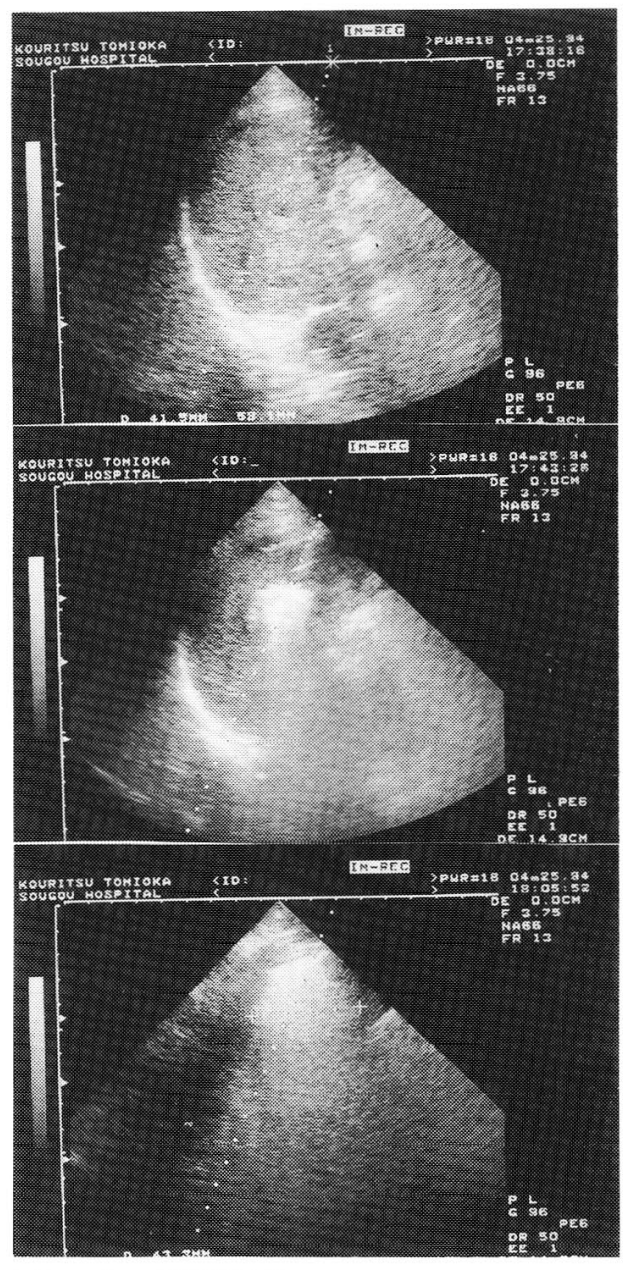

図3上：凝固開始前

中：凝固開始 5 分

下：凝固終了時（30 分後） 


\section{症例}

症例を供覧する。

症例 1 は65 歳男性, HCV 陽性で経過観察中に超音波 でHCCを発見された。CT, AGは図4，5のごとくで ある。

経動脈的制ガン剂投与, 塞检術 (Trans-arterialchemoembolization : 以下, TACE) を施行㣪PMCT (60W，30min）を施行した。
術後の CT では腫瘍の外側まで低濃度領域が広がり (図6)，充分に組織壊死が得られたことが証明された。 超音波で経過を見ていると，次第に㓔痕化して，病変 が縮小していく様子が観察された（図７）。

症例 2 は 62 歳男性, 検診で肝臓の腫瘍を指摘された。 CT, AG でHCC と診断した。60W，30分のPMCTを 施行した。PMCT 前後の MR 像を示す。PMCT 前は Dynamic-T1強調像で, 動脈㥵早期に濃染与る腫瘤と して描出されているが（図８），治療後ではLow-

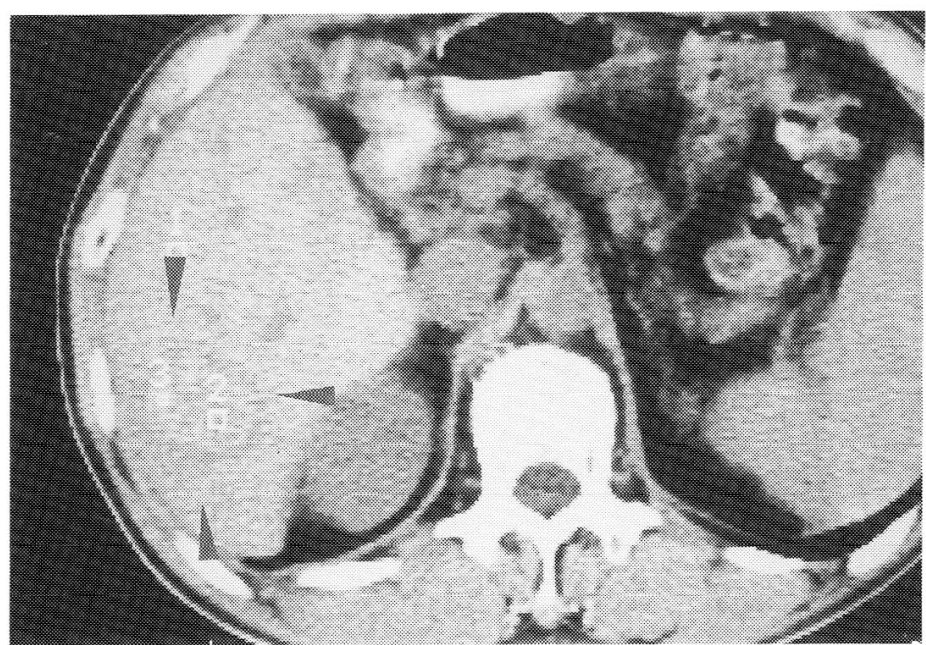

図 4

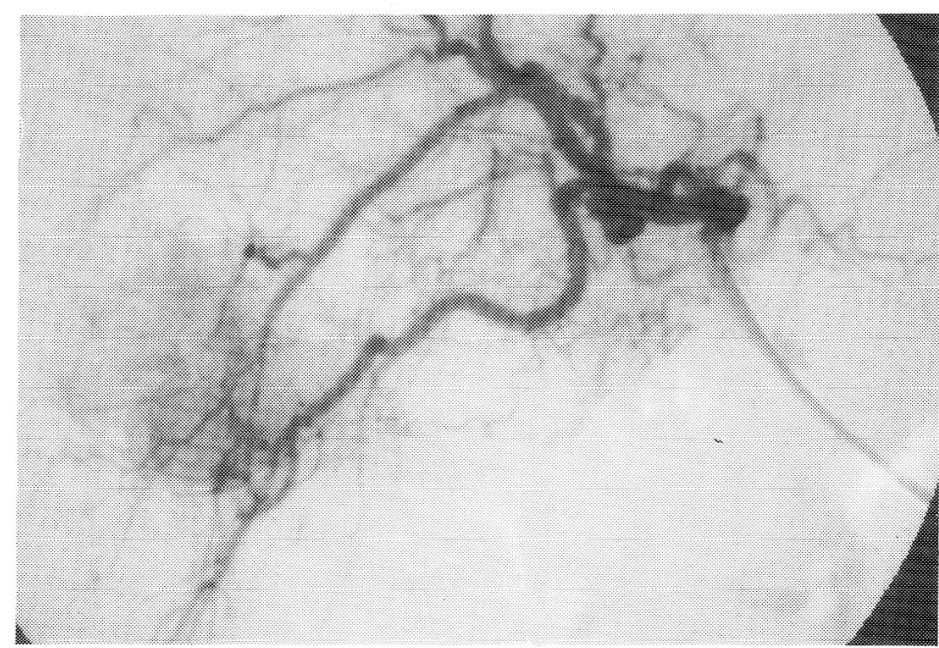

図 5 


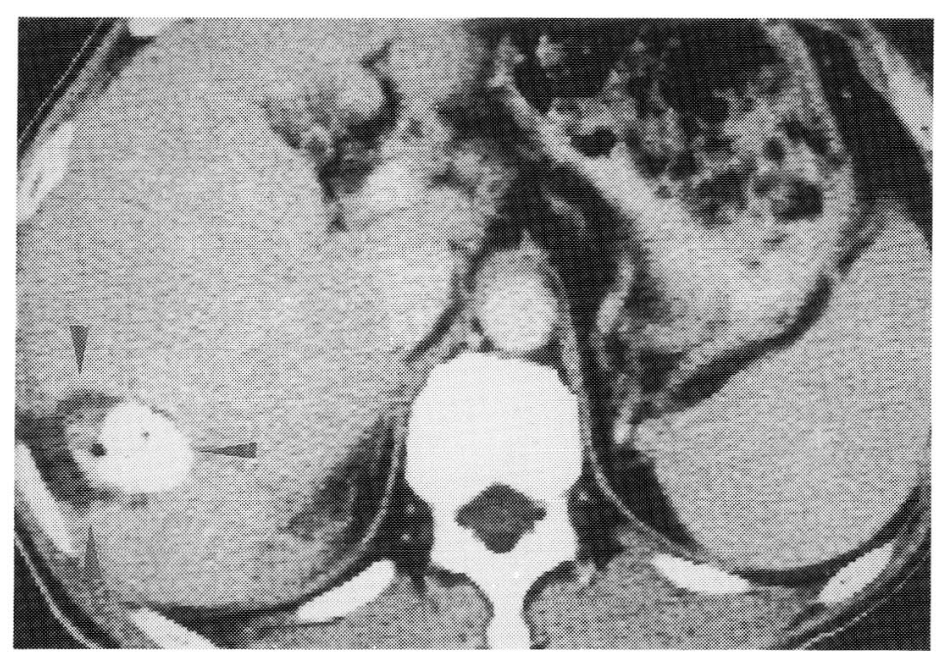

図6

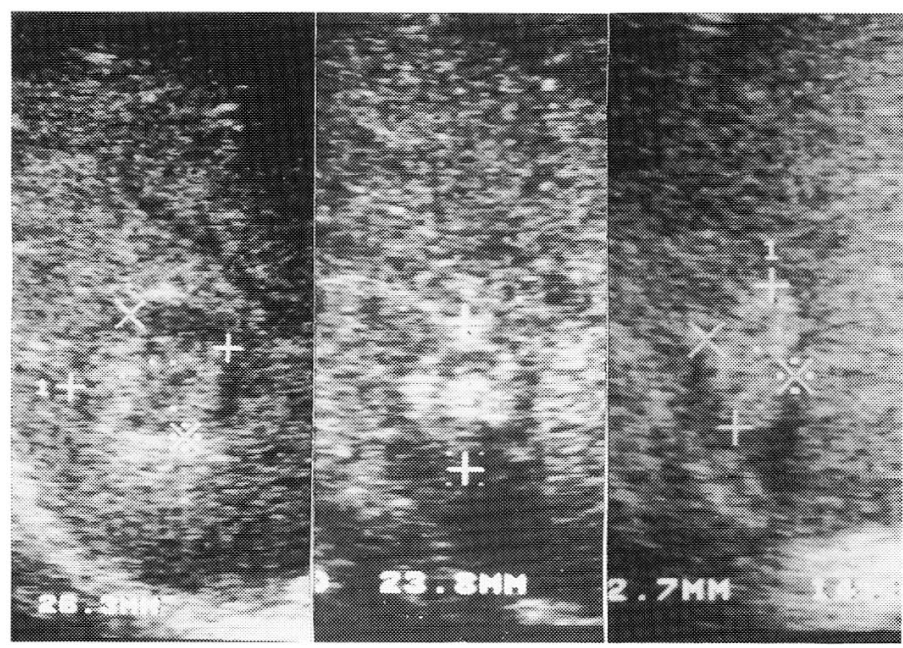

図7 左：治療後 1 日

中：治療後 1 ケ月

右：治療後 6 ケ月

densityに変化しており，その範囲も腫焬より一回り大 きい領域となっている（図 9)。これにより充分な marginをもって, 腫瘍がコントロールされた事が実証 された。

\section{考察}

肝腫瘍の治療として, 外科的切除, 経動脈的制ガン 剤注入塞栓術, 経皮的アルコール注入 (PEIT) が行わ
れてきた。その中で完全にまた確実に局所病巣をコン トロールできるのは, 外科的切除のみである。しかし 外科的切除は侵襲が大きく, 全身的体力や肝臓予備能 の点で，対象が制限される "。また切除に際して，物理 的な刺激を加えるため, 転移や残存腫瘍の急速な増大 を促進させる可能性もある。

TACEは侵襲は小さく, 繰り返し行うことが可能で, HCCの治療法として定着した 


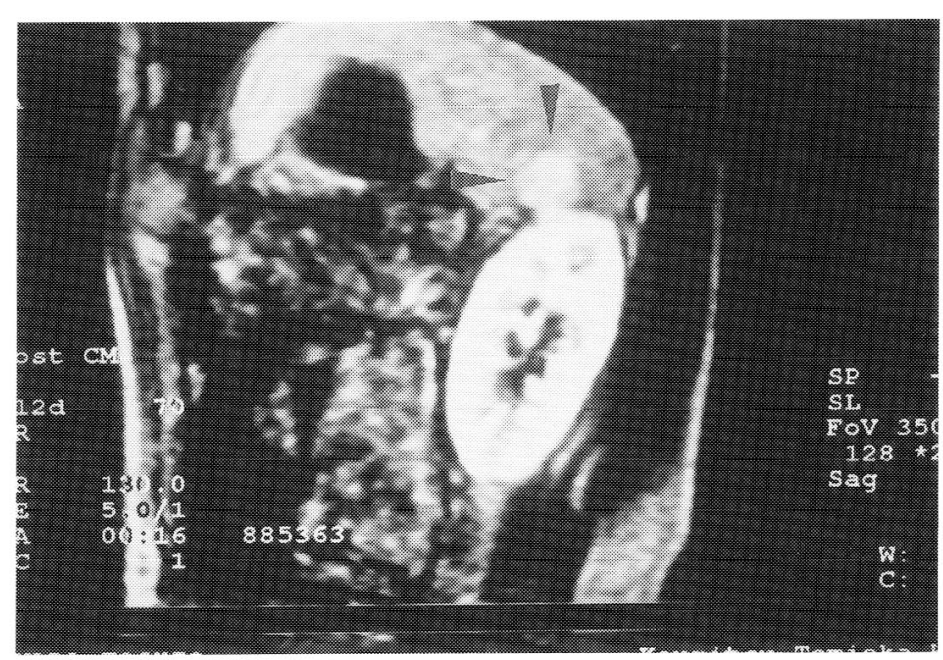

図 8

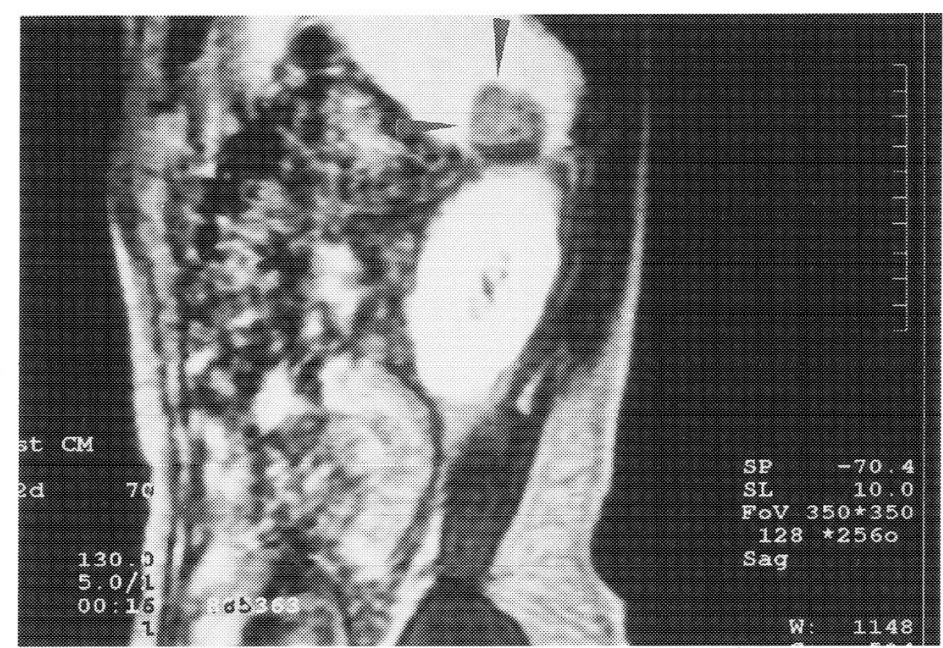

図 9

Variation や門脈血流量の点で, 治療不能例や無效例も あり，また転移性腫瘍に対してはほとんど効果は期待 できない。またPEIT ${ }^{3)}$ はさらに低侵襲であるが，極め て小さな病変に正確に穿刺することが必要であり，ま たアルコールの組織内拡散も曖昧であるため, 効果も 曖昧である。また転移性病変には，ほとんど無効であ る。

\footnotetext{
一方, PMCTは穿刺のみで侵襲が極めて少なく, 正
}

常肝組織への影響も少ないため゙, 肝予備能に関係なく 行える。また, 治療原理は誘電化熱による物理的加熱 であり, HCC, 転移性腫瘍の別無く, 確実な効果が得 られる ${ }^{4} 。$

問題点は，現在使用できる電極での出力に限界があ り，したがって治療できる腫瘍の大きさに限界がある ことである。現在我々が使用している直径 $2.2 \mathrm{~mm}$ の涙 滴型電極では, 前述した通り, 直径 $35 \sim 40 \mathrm{~mm}$ の腫瘍 
が治療の限界である。しかし，肝硬変や HCV 陽性者な ど, HCCの high-risk groupを厳重にfollow し, ま た消化器癌の術後を厳重にfollowしていれば，現在の 超音波診断では，直径 $20 \mathrm{~mm}$ 以下で確実に発見するこ とができると考える。

以上の観点より, PMCT は肝臟の腫瘤型恶性腫瘍の 治療法として極めて有効であり, 近い将来に, この種 の疾患の治療法として第一選択になるものと思われる。 さらに電極の改良で, さらに大きな病変の治療にも応 用できるものと期待している。なお，本論文の要旨は 第 94 回日本外科学会総会で発表した。
文献

1）幕内雅敏, 長谷川博, 山崎 晋: 肝硬変合併肝癌の手術 適応. 診断と治療, $74 ： 1225-1230,1986$.

2) 島村善行, 石井正則, 永田寿札: 肝動脈塞栓療法. 臨床 外科, $49: 325-330,1994$.

3）杉浦信之, 高良健司, 大藤正雄: 超音波映像下経皮的腫 瘍内エ夕ノール注入による小肝細胞癌の治療. 肝臓, 24 : 920, 1983.

4）才津秀樹，中山和道：マイクロ波による肝癌の治療. 日 本臨床, $51: 1102-1107,1993$. 